\title{
Istanbul, The Development of Islamic City Thinking
}

\author{
Hanif Budiman ${ }^{1, *}$ \\ ${ }^{1}$ Department of Architecture, Faculty of Civil Engineering and Planning, \\ Universitas Islam Indonesia, Yogyakarta, Indonesia
}

\begin{abstract}
The existence of a city is very important in civilization. It is not only as a physical habitat where a group of human lives together but also as a place where a community develops and becomes a noble and prosperous society. Islamic community creates a city as a means to create a physical, economic, social and religious environment. This paper discussed how the settlement of a city develops Islamic civilizations, from the period of the Prophet in Madinah, then spread to Arab, Africa, and Asian regions, bringing significant roles for the community. Istanbul, one of the important cities in Islamic civilization, grew with a combination of many traditions, from Hellenic, Byzans, Persia and later Islam; these traditions then underwent fusion as basic thinking to develop the city. This thinking was implemented in many ways, from the planning conceptions for the structure of the city, the unity of the main components of the city (palace, mosque, square and market), the settlement configurations, until the aesthetics of the city expressions.
\end{abstract}

Keywords : city, islam, ottoman, civilization, development

\section{Introduction}

Prophet Muhammad (Peace Be Upon Him) was born in $570 \mathrm{C}$ in Mekkah, which at that time, for the regions, Mekkah was called "the mother of villages ", and had long become an important destination for many tribes around Arab to make the pilgrimage. The main destination in Mekah was Ka'bah, the center of pagan worship activities.

\subsection{Early Islamic City Situation}

After receiving revelation in $610 \mathrm{C}$, the Prophet spent 13 years living in Mekkah to start and develop Islam. In 620, a group of Muslims migrated to Abyssinia to escape the persecution in Makkah. However eventually, the Prophet and the Muslim community had to migrate (hijrah) to Madinah in $622 \mathrm{C}$. In fact, the Prophet had investigated Madinah for 3 years before they finally hijrah. The main consideration of hijrah was because in Makkah or other places (even in Thaif / Khaibar) there was no place to be made as a centre (merkez) for developing community. Previously, this was a city named Yatsrib, but then the Prophet

* Corresponding author: habudiman@uii.ac.id 
changed it to Madinah, meaning the city or civilization. In Madinah, muhajirin (migrants from Mekkah ) were received by anshor (helpers for the migrants).

Prophet Muhammad conducted strategic steps to build Madinah as the center of Islamic civilization. The steps were carried out by making mosque as the center of the community and then building a market to support the basic needs for the community. Previously, the location of the mosque was in an empty field overgrown with date palms and a part of the field was the grave for some Madinah inhabitants. The Prophet bought the land from the owner, two orphans from Bani Najjar. He also invited his companions to make preparation activities for the land, and then the construction of the mosque began. The Prophet led the construction activities of the mosque by himself. The mosque was built by using desert rocks, mud walls, date palm trunks for the columns, and the leaves of date palms as the roof material. Initially, the area of the mosque was $60 \times 70$ cubits (about $30 \times 35$ meters) with 3 gates and a courtyard in its centre. The Prophet made the mosque face Baitul Maqdis as the first direction of worship (qibla). To guide the life of the community in the city, a Quranbased independence community system was created. The mosque had several functions, including a place for worship, as well as the center for social and political activities of the nascent Muslim community.

\subsection{Basic Principle of Islamic City}

Why the Prophet firstly developed a city community to start civilization is understandable. Ibn Khaldun said that a criterion of human civilization is to build cities, where a fixed life and system will be established. (Karataş, 2016 ). In his Muqadimah, Ibn Khaldun also emphasized that this sedentary system needs to consider some special situations during the establishment of cities, namely the security, environmental health, agriculture, and transportation. The Prophet lived for 10 years in Madinah and built Madinah as a model for the next Islamic communities. Madinah was developed into a prosperous city which was due to a close relationship among the mosque, souq, streets, and houses, that surrounds as a good neighborhood understanding. In term of situations, there were some basic principles in the formation of Madinah evolving as an Islamic city (Soud, 2002), such as:

\subsubsection{Natural Law}

It is about how a community makes some adaptations in relation to the weather conditions and topography. The elaboration activities for these adaptations were actualized in making spatial planning and design such as a courtyard, terrace, narrow covered and gardens.

\subsubsection{Religious and Cultural Beliefs}

This is the principle that makes mosque as a central position in spatial and institutional hierarchies. However after Islam grew in Madinah and spread to other regions, the mosques developed significantly, such as city mosque (Jami mosque), regional mosques and community mosques.

\subsubsection{Sharia Law}

This is the Islamic principles that manage physical and social relations between public and private realms, and between neighbors and social groups relationships. 


\section{Spread and Development of Islamic City}

The whole civilization of the non Arab countries, or the largest part of it, such as Syria, Egypt, Iraq, Spain, and similar countries was one of the villages, cities, and districts. Muslim came to these regions, make Dar El-Hijra, a place when Muslim came to put practice the Islamic life and through them Islam spread to North Africa, then the whole African and Southern Europe.

\subsection{Ummayah}

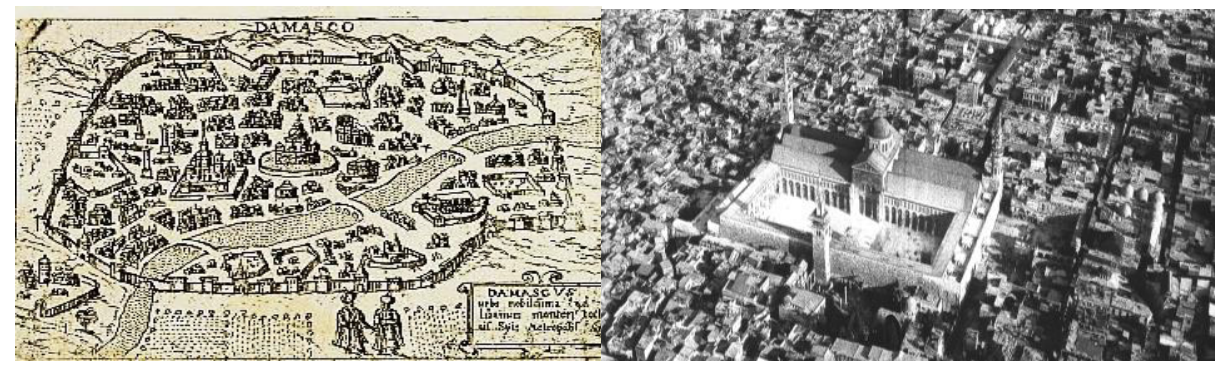

Fig. 1. Map of Damaskus and Area of Mosque of Damascus

Muawiya claims as the caliphate, and begin the Umayyah dynasty from 661 to $750 \mathrm{C}$. In Umayyad period, Damascus city was the capital and was known as the Umayyad style or Syria style, which marked the establishment of palaces and attention to decoration. It was no longer a mosque centered city as in the past. The separation of home principality from the mosque because of the differences that occurred at the beginning of the Umayyad rule, the focal attention deficiencies occurred since the beginning of the Umayyad ruling. The appearance of the yard in the center of the house, located symmetrically on the left and right suites, were works of extinction which represented the class known as Hairi. (Urtaberta, 2012 )

\subsection{Abassid}

After the Ummayah period, Islamic caliphate was moved to Abbasid caliphate ( 750-1258 C ), and capital moved to Baghdad city. During the Abbasid caliphate era, many cities were built and different approach was elaborated as basic of planning and design thinking. Baghdad was known as the round city or City of Peace (Madinat al-salam).

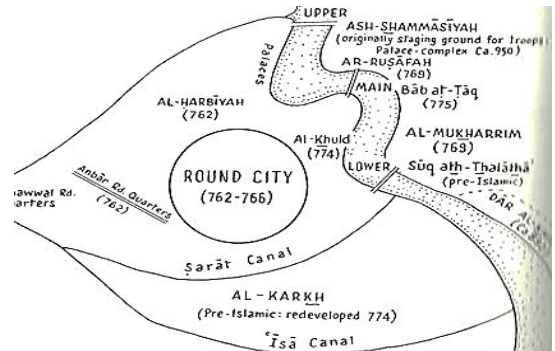

Fig. 2. Map of Baghdad city situasions

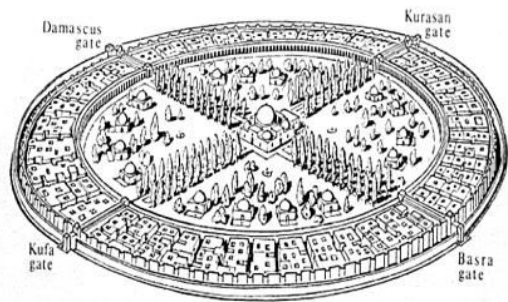

Fig. 3. Image of Baghdad Round city 
Al-Mansur caliph (762-755 C) brought many technicians and artists from Syria, Persia, and Babylon to build his new capital. One of Baghdad's gates, the Khurasan gate, was brought from Syria. It is thought to have been made by an Egyptian artist following a Pharaonic plan and style. During the reign of caliph later, Harun al-Rashid (786-809 C), Baghdad reached its golden age. ( Al - Khazwini, 1969 ). Baghdad city became a major commercial, social and knowledge center of regions, and grew as one of most iconic capital in architecture history. Previously, at the time of the Prophet and Rashidin successors, the mosque had combined several functions, such as a place of worship, the social and political center of the nascent Muslim community, but under the Abbasids, the mosque developed a new character as an exclusively religious institution. Each of the four gates to al-Mansur $\mathrm{s}$ Round City possessed a complex, bent entrance passage designed to guard it against violent attack. Each gate was surmounted by an elevated chamber reached by staircases or ramps. Each of the chambers was crowned by a dome, and the whole 50 -cubit ( 82 foot, 25 meters) structure was topped by a weathervane in the shape of a human figure. Centrality here expresses political power, and the concept is that everything emerges from the center. Here, power overcomes climate as the principle shaping factor in the hot arid zone city.

Several settlements stood outside the walls of the city, a great army camp stood at Harbiya, markets were located in al-Karkh, and al-Mansur's son al-Mahdi built a subsidiary camp for his troops on the east bank of the Tigris at Rusafa. The Round City soon failed to achieve its original purpose, as the population regulated thickly around it, and even the administrative core was quickly transformed into a normal urban entity. In $1258 \mathrm{C}$. Hulagu Khan sacks Baghdad. End of the Abbasid Caliphate of Baghdad. The curtain falls on the classic Islamic civilization.

\section{Istanbul City}

\subsection{Basic Thinking}

A great turning point in city's history occurred in AD 330 when Emperor Constantine moved the capital of Roman Emperor from Roma to Byzantium. The city swiftly named as Constantinople and began made re-organizing the old city to the modern city. Geographically, the city was formed by seven small hills, commanded the Bosphorus and Golden Horn. The Bosphorus physically separates Europe and Asia, but culturally unites two continents.

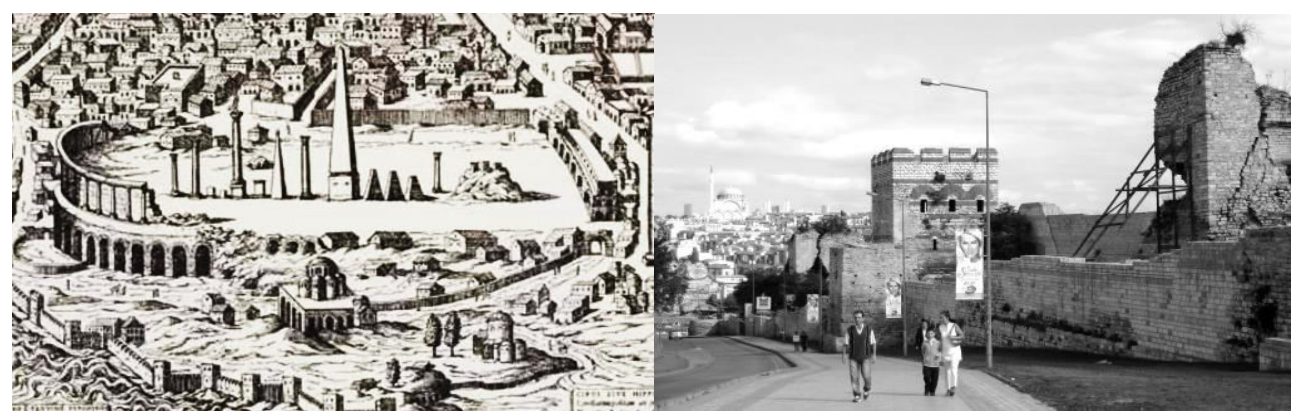

Fig. 4. Constantinople at Byzantium era

Fig. 5. Theodosius Wall in Istanbul

During the re-organizing era, the city experienced a population boom. From 25.000 people, city population had grown to 100.000 in less than a century. The important decisions taken by Constantine was the adoption of the Rome administrative structure for his new capital. 
The city divided into 14 districts, each run by a curator. This system worked so well, and it was continued by the Turkish rules after the Ottoman conquest. ( Gul, 2013 ).

Expansion of the Constantinople city was happened at the time of Theodosius and Justinian Emperor era, from 5 until 6 Century. Theodosius built more long and strong city walls with double layers and observations towers. It was the last fortification built for the Constantinople city and survives until today. Hagia Sofia ( 537 AD ) was the important major structure which built by Justinian Emperor, and strongly affected and dominated Constantinople skyline. He was also built the palaces, cisterns, hospices, and many smaller churches. Constantinople city then grew very rapidly, since its strategic locations, and as important harbor and commercial centre in Eastern Medditeranean and Black Sea region. Along with this era, were established various residential colonies in a different part of the city.

\subsection{Ottoman Era}

Once the capital of Roman, Byzantine, and Ottoman, reflects the unique values of these cultures through urban, historical, archeological and natural sites and numerous monuments. Mehmet II conquered Constantinople city in $1453 \mathrm{C}$, and then renamed this city like Istanbul and then made it as the capital of the Ottoman Empire. Istanbul is one of the best examples to see how Islamic city tries to develop based on its own complex, different and unique characters of the city.

In order to establish the Turkish and Islamic character of Istanbul, new programs were immediately put in place after the conquest in 1453. After that, Ottoman required to select suitable sites in Istanbul to built mosques, baths, and marketplaces and gave names to the districts. Sultan also chose a topographically significant location for the grand mosque as the center of the community. The Fatih mosque was completed in 1471 and developed as Istanbul's first kulliye (a complex consisting of a mosque and surrounded by a group of public buildings such as hospital, schools, dormitories, baths, kitchen, libraries or hospices). In many Ottoman schools, students not only learned Islamic knowledge but also learned physical and social science such as psychology, military, medicine, law, mathematics, astronomy etc. This kulliye once again served as the center of a new developing mahalle (neighborhood).

This was the place where ulema (religious elite) and administrators of the highest rank went to school. Many structures were set up as endowments or waqf. Thus, the city started to develop a series of such waqf complexes, created by the sultans and other members of the ruling class, including high positioned women. Other less prominent individuals also had the freedom to finance the construction of smaller waqf complexes with a mescid (small mosque), its medrese (schools for high education). The charitable and religious endowments (wakf's) were established to foster the welfare of the population and to build the infrastructure of the city in general, such as water-supply, paving of roads, public security, hospitals, street-cleaning, shelter and feeding of the poor and travelers.

The Ottoman urbanization process was very complex and characterized by interconnections between different cultures. The cultural syncretism of the Ottomans was heir to a longstanding nomadic culture that had always included, appropriated and embodied elements from different cultures. (Kaçar, 2012). Based on the cultural, natural and historical continuity approach, from the beginning of the city development in the Ottoman era, mosques had been planned as a main component of the city image or community ( mahalle ) character. Comprehensively this basic design thinking was applied in the plan configurations and visual arrangement and harmoniously supported by kulliye, bazaar, hamam, caravanserai, and settlements. 


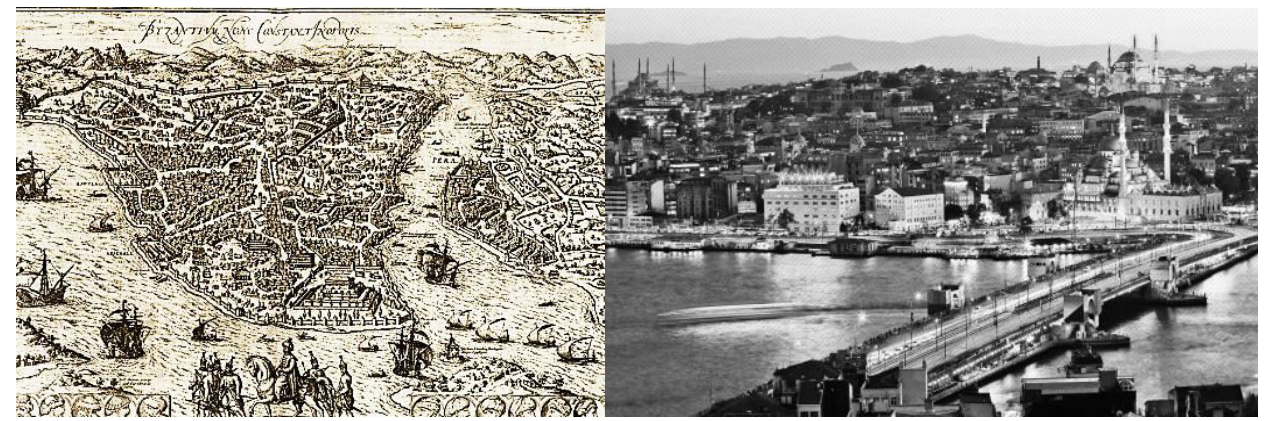

Fig. 6. Old map of Istanbul

Fig. 7. Historic area of Istanbul city recentdays

\subsection{City Plan and Development}

Despite the growing pace of political reforms in 19 Century, Istanbul was still a chaotic, overcrowded, poorly serviced and badly administered city. One major problem was the catastrophic fires which occurred every few years, resulting in the loss of thousands of timber buildings. The city's urban pattern was narrow crooked street, many with cul de sacs. The dramatic increase in urban populations, largely from the lost territories of the Empires, put great pressure on the already inadequate civic service. With no planning control of the city, especially its residential quarters, the existing pattern had to be rebuilt many times. ( Gul, 2013 ).

\subsubsection{City Development}

The making of Istanbul also followed the urbanization pattern of the earlier Ottoman capitals. The two basic features of the Ottoman city (as in Bursa or Edirne, former Ottoman capitals) were a royal mosque and around it a district of a commercial center. This city pattern also appeared in Istanbul, which started with Aya Sofya mosque and its Bedestan (commercial center with shops, etc). The concentration of major mosques in Istanbul can be explained in political terms as a part of a sustained attempt to transform the visual aspect of the ancient Christian city of Constantinople to give it a new Islamic identity as Istanbul.

\subsubsection{Mosque, Kulliye and Settlement Development}

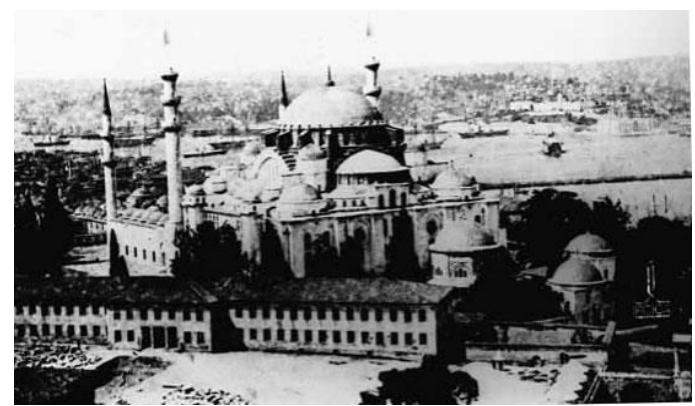

Fig. 8. Suleimaniye Cami and medresse around

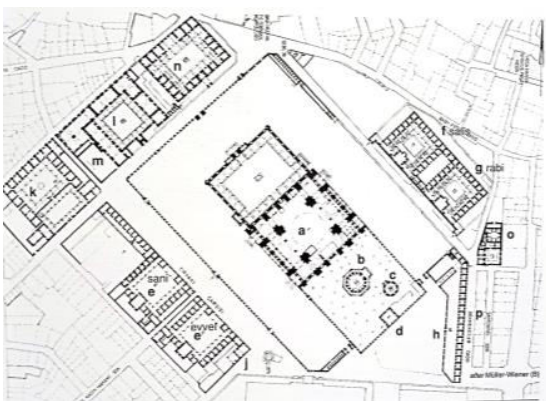

Fig. 9. Suleimaniye Kulliyesi in Istanbul 
The relationship between muhajirin and anshor companion principle from the Prophet era still continued in the Ottoman era and interesting since this situation is also still going on in the modern life of Istanbul today. Çesmesi (fountain), sebil (dispenser for a free drink), imaret (kitchen for public food) still function as a public service for people in urban daily life, side by side and balance the bustle and dynamics of the development of the modern life of Istanbul. In addition, the existence of important mosques of the city still functions as a center for urban community and district. For example Suleimaniye mosque and the Suleimaniye kulliyesi. This important kulliye complex (mosque and public facilities around it) was built by Kanuni Sultan Suleiman and designed by Mimar Sinan based on the strategic Istanbul urban setting. Sinan created the configuration of the mosque (domes with minarets) by respecting the potential to Golden Horn scenic and the whole of geographic situations of Istanbul urban setting. Like in most Islamic cities, it makes the mosque as the center of urban living, not only in terms of social aspects but also in terms of aesthetical consideration as well.

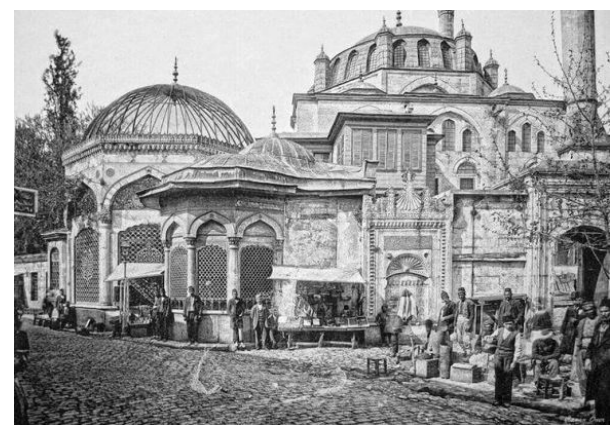

Fig. 10. Ottoman sebil in Üsküdar, 1814

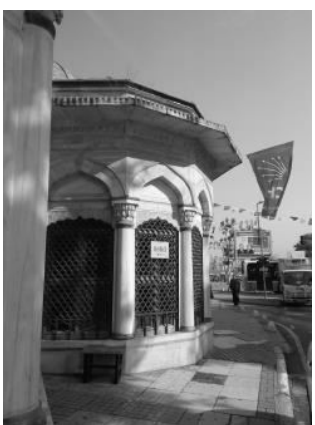

Fig. 11. Ottoman sebil in Üsküdar, 2018

In terms of the settlement or housing development, there were some adjustments made by people since the Istanbul urban pattern looked like very organic winding and narrow street because of its hilly conditions. People adjusted this condition by making the balcony (overhanging upper part of the house for the second floor) and tried to follow the straight street line, while the base part was still performed with organic winding street. But the earthquake in 1894, followed by fires and new urban planning with grid layout, resulted in major changes, especially in the urban fabric of the Historic Peninsula region (Fatih and Old city area). Road widenings in the mid-twentieth century created a lot of damage to the old buildings. There were many new rooms for apartments or office with four or five stories.

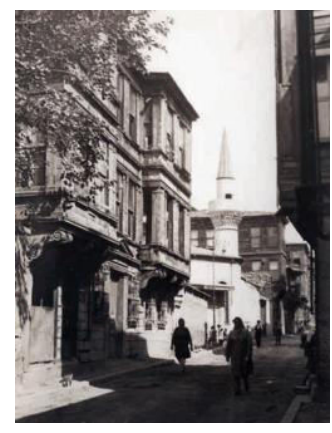

Fig. 12. Settlement in Istanbul in early 20 Century

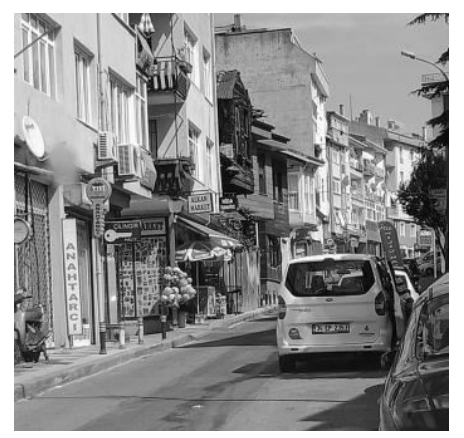

Fig. 13. Settlement in Istanbul in 2018 


\subsection{Europanizations}

Europeanization of traditional Islamic city occurred in many lands, from Arab regions until Africa regions. Europeanization of Algiers started by the French $(1830-1962)$ in an attempt to eradicate the Islamic identity and now this beautiful city suffers from continuous neglect. (Soud, 2002). In Cairo, the modernization of the old city continued by making a new park near Al Azhar University (1984). The concept of design tried to respect Islamic traditions and, inspired by Andalusian and Persian gardens, the park used references positioning Cairo at the center of a cosmogony referring to a golden age and a "golden geography" of Islam. One of the interesting things is, they kept the Cairo's old view as the basic design. (Madoeuf, 2009).

In Istanbul and Turki in general, Europeanization began when the Ottoman Empire's politics declined in the mid 17 Century. It was a long festive session in the Ottoman history where the seeds of secularism were first sown in Turkish culture as it began to absorb European ideas. The opening of libraries, establishment of Turkish first printing press, translation of the classical text into the Turkish language, also flourishing poetry and literature, were the most important markers in the socio-cultural life in Istanbul during the Tulip Era. (Gul, 2013). During the Tulip era, Istanbul city had many large scale constructions of timber pavilions, palaces and parks along the shores of Golden Horn in Historic Peninsula and the Bosphorus straits. The other important thing from this phenomenon was the fusion of Ottoman with European Baroque Rococo styles. This combination created a unique Turkish Architecture. In the 19th Century, there was the implementation of the first building codes and regulations in Istanbul as an imperial capital city intended to prevent any catastrophic fires and improve civic services. Even though many new principles was tried to aplicated, but generally the Europanization program for district still looked like as an integrated fragmented ordering, and also still accommodate the physical, social and religious community considerations as whole.
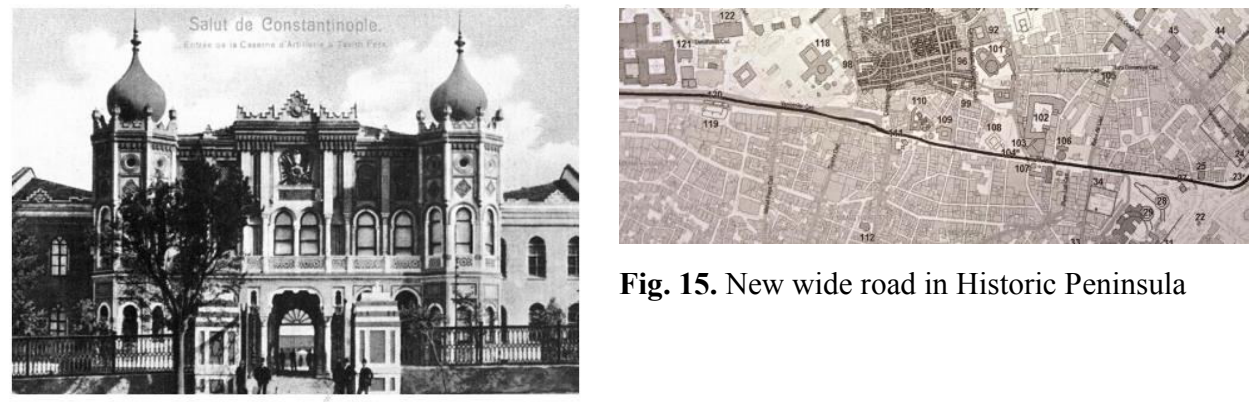

Fig. 15. New wide road in Historic Peninsula

Fig. 14. Ottoman Building in

Europanization era

\section{Conclutions}

It is a fact that the Islamic community has greatly contributed to the development of the world's civilization, including the thought of Istanbul city planning and design. From the early development in Madinah then spread in Arab, Africa, Middle East regions, India until South East Asia, some basic thinking and principles had developed gradually, based on the natural, social and cultural conditions in some regions. Islamic cities grew physically, aesthetically and comprehensively with some elaboration of different considerations.

Istanbul generally has a unique positioning in terms of global Islamic city discussions. This is due to the character of urban and architectural history as one of the most complicated 
cultural civilizations. As a city in the Mediterranean region, Istanbul originally grew as a settlement based on natural resources with trade traditions. Greece, Roman, and Byzantium cultures affected the city with symbolic aspecs,, and implemented in city planning in term of the relations among the existence of palace, church and settlements. Later, the important period was when Islamic thinking strongly affected the unity of the palace, square, mosque and market. Islamic character developed the mosques and built environment as a center of mahalle (district) and grew as kulliye (a complex consisting of a mosque and surrounded by a group of public buildings such as hospital, schools, dormitories, and kitchen). This is the expanding of the basic principles of Islamic city. In term of sustainability value of the city, in Istanbul, one district is still connecting with the others and making the city as integration of physical, social and religious community as a whole. The other important situation for civilization is how the existence of public facilities in Istanbul such as mosques, çesme (fountain), sebil (free drinking water), kitchen etc, still functions as a public services for urban community and district, which is this situation actually have been established and started from the Ottoman period.

Based on Istanbul history and experiences, these paradigms, principles, values together with social and cultural norms, still have a big opportunity as the main approach to making appropriated helping address current urban challenges in the city's modern situations.

\section{References}

1. Al-Kazwini, B.M., The Abbasid palace an analytical study of its wall-ornaments, ( Durham theses, Durham University, 1969 ).

2. Batur, Prof.Dr.Afife, Historic Peninsula, ( Chamber Of Architecture of Turkey Istanbul Metropolitan Branch, Istanbul, 2006 )

3. Blair, Sheila, Islamic Architecture - Abbasid Period, ( in http://islamicarts.org/2011/architecture-of-the-abbasids-iraq-iran-and-egypt/ 2011).

4. Gul Murat and Trevor Howells,Istanbul Architecture, ( The Watermarks Press, Boorowa, Australia , 2013 ).

5. Ibn Khaldun, Abd Ar Rahman bin Muhammed, The Muqadimmah, translated by Roshental Franz, edited by Dawood, NJ, ( Princeton Publising, 1967 ).

6. Kaçar, Hilmi, An Islamic City : Konstantiniyye/Istanbul: Constructing an Empire on a City ( www.academia.edu, 2015 )

7. Soud, Rabah, Introduction to Islamic City, ( Foundation Science For Technolory and Civilizations, Manchester, UK, 2002 )

8. Urtaberta, Nakula, Architecture in Islamic Civilization, 2012 ( in https://www.researchgate.net/publication/274712337_ARCHITECTURE_IN_THE_ISL AMIC_CIVILIZATION ) 